\title{
The Impact of Outdoor Education and Outdoor Game on Self Concept and Assertive Behavior
}

\author{
Teguh Satria*, Herman Subarjah, Kardjono Kardjono \\ Universitas Pendidikan Indonesia \\ Bandung, Indonesia \\ *teguh2662@gmail.com
}

\begin{abstract}
This study aims to test how big the impact of Outdoor Education and Outdoor games are against the Selfesteem Concept and behavior of Assertive Students Elementary Laboratory Pilot UPI Tasikmalaya. The sample in this research totaled 32 students, techniques the taking of purposive sampling. Method the authors use in this research is a method Experiments. Instrument used questionnaire Self-Concept Scale, and the Assertive Scale. The results showed that, Outdoor Education and Outdoor Games impact significantly to Self-Concept and Assertive behavior. Suggestions for further research, with a treatment such as Pool Games against self-concept and assertive.
\end{abstract}

Keywords-outdoor education; outdoor game; self concept; assertive; gender

\section{INTRODUCTION}

Schools faced by students today become an obstacle in carrying out a good educational process. This modern era has more students who do negative things that lead to behavioral deviations in their growth and development, commonly referred to as juvenile delinquency. A lot of news in electronic media and newspapers about students who fight, drugs, fights, free sex and other deviant behavior both in school and outside school, this proves the portrait of students now. Violations of school rules were carried out by students, including carrying electric cigarettes, using communication equipment during class hours, not entering during mid-school hours, skipping school, damaging school facilities, and other less commendable behaviors. Recorded in the book handling cases, violations were mostly carried out by students compared to students. The above description describes a portrait of students who do not dare to express their own wishes and opinions that might occur, the individual will be exploited and easily influenced by others.

Outdoor education is well aware, ensuring regular access to the outdoors is only part of the puzzle of inspirational relationships with nature that produces results that benefit people and the planet. To inspire relationships with nature that turn to everyday life and have a lasting impact, it has been argued that outdoor educators must focus on maintaining cultural dynamics that support the appreciation of nature, sensory variety $[1,2]$. Outdoor education can contribute to the development of self-writing because of its similarity to constructive teaching pedagogy.

The game has a very important role in developing cognitive, affective, and psychomotor power for students. This is as shown by the study Rusmana Nandang, that game techniques can be used as a vehicle for counseling and psychotherapy, especially for victims of post-earthquake disasters, can also foster a sense of empathy for both parties, so that it will facilitate adjustment to conditions that is, because the function of the game is to issue problems in a person [3].

The self-concept of children with learning abilities has become quite a research topic. Studies show that children with learning abilities have social and emotional problems and in their academic performance. Indeed, these children seem to show reciprocal effects between academic and emotional functions. For example, continuing academic failure tends to contribute to low self-concept. At the same time, children with low self-concept may not try tasks where they can succeed. The fewer areas where the mastery of children's experiences, the more negative their self-concept. A number of studies have raised the question of whether children with learning disabilities have more negative self-concepts than other children [4].

With regard to assertive behavior, students can interact well and effectively with other students, teachers, or other teaching staff. This is very beneficial for itself, because with good communication and interaction it will facilitate the flow of information in the learning. Good interaction between students will make learning atmosphere enjoyable. Thus it will make these students motivated to study harder [5].

Through Outdoor Education and Outdoor Game activities, it is expected that elementary school students can become better, avoid negative traits such as juvenile delinquency in the future. Hopefully these activities can provide benefits for students so that there is a change in behavior, raises selfconfidence, has confidence in their ability, optimistic, objective, responsible for everything they do, can think rationally and act realistically.

\section{RESEARCH METHOD}

The research method used in this study is the Experimental method [6], the research design used in this study is True Experiment with pre-test-post-test control group design. This refers to that this research will be conducted early tests to determine the condition of Self-concept and Assertive behavior in elementary school students; namely to see changes in attitude in learning. 


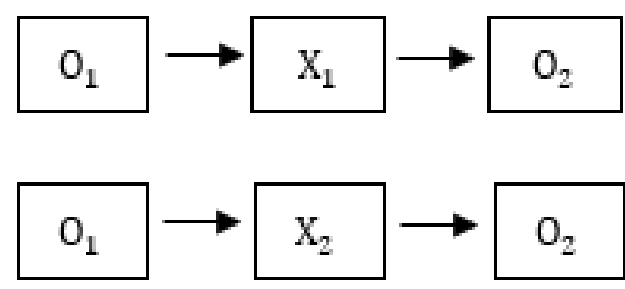

Fig. 1. Research design.

The subjects who will be involved are 10-11 year old children, Tasikmalaya UPI Pilot Laboratory Elementary School. The number of samples in this study were 32 children using the purposive sampling approach, the Experimental Group of 17 students and the Control Group of 16 students. The instrument used in this research is Kioner. The use of this instrument is based on According to Riduwan [7], a closed questionnaire is a questionnaire that is presented in such a form that the respondent is asked to choose one of the answers according to his characteristics by giving a cross (X) or checklist $(\sqrt{ })$. Because of the instruments, this is quite representative and can contribute to getting data to see the attitudes and behavior of children aged 10-11 years.

\section{RESULTS AND DISCUSSION}

The data obtained in this study is to do the initial test first to find out the initial data or attitude before the treatment of the Outdoor Education and Outdoor Game learning methods, after the treatment of the method, the researcher then conducts a final test to determine whether or not there is an improvement of the method. this. The data processing method in this study is by using the SPSS Version 22 application. The following is the result of processing the data described by the researcher in the form of the SPSS Version 22 application that can be seen.

\section{A. Results of Initial Test Data, Final Test and Improvement}

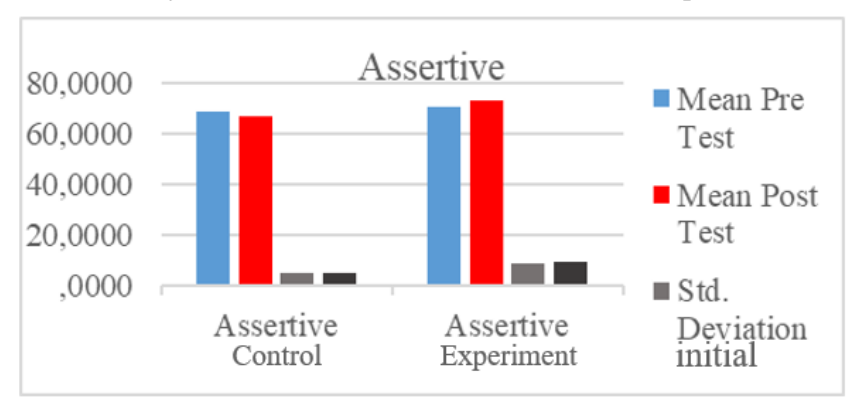

Fig. 2. Results of initial test data, final test 8 and assertive experiment.

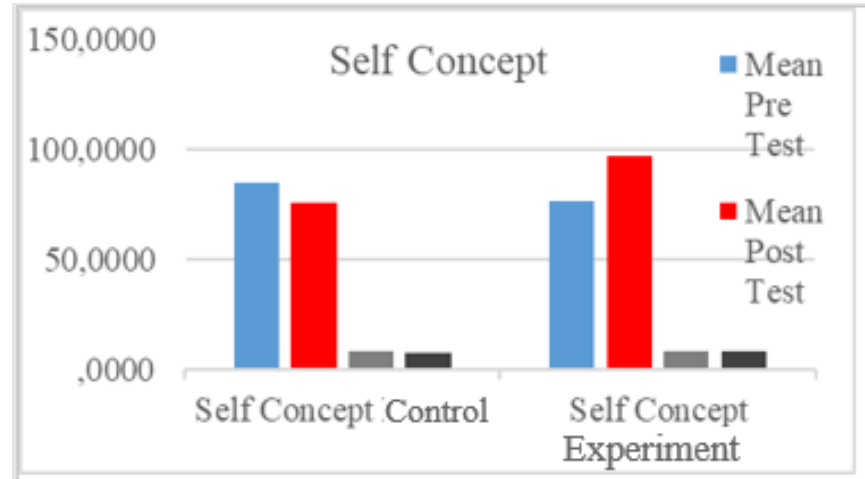

Fig. 3. Results of initial test data, final test self-concept control and selfconcept experiment.

After the mean, standard deviation and increase are known from the initial test, the final test and the increase, then the next step the researcher does is to look for a normality test. From the table above it is known that the significance values are: 0.690 , $0.876,0.972,0.492,0.799,0.662,0.504>0.05$, so Ho is accepted. So it can be concluded that the distribution of the three variables is normal.

\section{B. Outdoor Education and Outdoor Games can Have a} Significant Impact on Self Concept and Assertive Behavior on Elementary School Students of Tasikmalaya UPI Pilot Laboratory

The learning process in outdoor education activities is basically by providing the widest opportunity to gain direct experience. Mastery of the concepts of sound and knowledge relating to humans and natural resources. Life skills that produce health, prosperity, creativity, refreshing way of living, and positive attitudes that reflect human and natural harmony. There are three main concepts of outdoor education, namely the concept of the learning process, the concept of outdoor activities, and the concept of the environment. First, this learning concept implies that learning through out-of-class activities is an interdisciplinary learning process through a series of activities designed to be conducted outside the classroom. This approach consciously exploits the potential for natural settings to contribute to physical and mental development. Increasing awareness of reciprocal relationships with nature, programs can change attitudes and behavior towards nature [2].

In accordance with the conditions in the field, researchers have had a significant impact on attitudinal changes with Outdoor Education and Outdoor Game learning methods. Why is it like that, because by running in the open it is very good, even better if done in the highlands such as mountains that vary in the form of its beautiful topography, with changing natural landscapes, this will not only make the mind and mood more comfortable and good, like doing meditation makes children's self-concept positive.

Behavioral changes in the learning process occur due to interactions with the environment. Interaction usually takes place intentionally. Thus learning is said to be successful when there is a change in the individual. Conversely, if there is no change in the individual, learning has not been said to be 
successful. We cannot inhibit technological development or reject it, but by optimizing ourselves and our ability to be more in tune with nature, we hope and are very important.

Based on the observations of the researchers, there was an amazing interesting impact on children, namely cheerfulness and (Self-concept), emotion or mutual respect, even often felt empathy when doing camping and hiking and also when in the game the implementation of research. Please help make a solid feeling of brotherhood, making the environment feel comfortable and warm. Even independent individuals appear and can lead as (assertive) behaviors to their friends in collaborating and solving problems while in implementation.

At the time of the research process, the obstacles faced were the time used in conducting the research, and the permission of the parents and the school, which should have lasted for three weeks, two meetings on Friday and Saturday. On Friday the Outdoor Game is scheduled to be located in the surrounding area of the Tasikmalaya UPI area, and continued to the campsite, then Saturday conducts Outdoor Education to the Urug Mountains area on the border of Tasikmalaya city.

In this study divided into two groups of research samples, namely the experimental group and the control group, the experimental group followed for 6 meetings. While the control group only outbound. Obstacles to parental and school permits make the study constrained and the maximum impact of the research results is not maximal.

In the research program, it was scheduled in 6 meetings but it was constrained, namely the need for 3 camping meetings, but only 2 meetings were held, the first week went smoothly, in the second week it even clashed with the scout schedule that carried out the camp as well. In the third week the school did not give permission because they did not get permission from the parents. These constraints do not make the end and can be overcome so that the research gets results and can run smoothly. It would be better if the camping could be carried out according to the program that had been planned, namely during 3 meetings, according to the reference of the previous research theory.

\section{CONCLUSION}

Investigation of the results of data processing and analysis that has been carried out, can be concluded as a behavior change in the learning process occurs due to interaction with the environment. Interaction usually takes place intentionally. Thus learning is said to be successful when there is a change in the individual. Conversely, if there is no change in the individual, learning has not been said to be successful. We cannot inhibit technological development or reject it, but by optimizing ourselves and our ability to be more in tune with nature, we hope and are very important.

Character education through Outdoor Education and Outdoor Games before arriving at behavioral change, through Outdoor Education and Outdoor Games, researchers want to convey that basically Outdoor Education and Outdoor Games are educational activities conducted in the open. All learning activities that are usually carried out in the school environment are transferred to the nature of the hills, rivers, caves, beaches and various places in nature. This activity aims to develop all the potential that students have both in terms of skills, knowledge and attitudes and how to instill in students to love nature. It has been shown that participation in outdoor activities increases emotional well-being because the natural environment can moderate the effects of stress, which results in anxiety, decreased depression and changes in positive attitudes.

\section{REFERENCES}

[1] B.S.R. Grimwood, M. Gordon and Z. Stevens, "Cultivating Nature Connection: Instructor Narratives of Urban Outdoor Education," Journal of Experiential Education, 2017.

[2] G. Bento and G. Dias, "The importance of outdoor play for young children's healthy development," Porto Biomedical Journal, vol. 2, no. 5, pp. 157-160, 2017.

[3] N. Rusman, Konsling kelompok bagi anak berpengalaman traumatik pengembangan model konseling kelompok melalui permainan untuk mengatasi kecemasan pascatrauma pada anak-anak Korban Tsunami di Cikalong Tasikmalaya. Desertasi Bandung: SPS UPI, 2008 Unpublished.

[4] S. Kloomok and M. Cosden, "Self-Concept in Children with Learning Disabilities: The Relationship between Global Self-Concept, Academic "Discounting," Nonacademic Self-Concept, and Perceived Social Support. Learning Disability Quarterly, vol. 17, no. 2, pp. 140, 1994.

[5] A.B.V. Rijn, Steensma, B.P.C. Kreukels and P.T. Cohen-Kettenis, "Selfperception in a clinical sample of gender variant children," Clinical Child Psychology and Psychiatry, vol. 18, no. 3, pp. 464-474, 2013.

[6] J.R. Frengkel, How to design and evaluate resech in education. Amerika, new York; Mcgraw-hill, 2012.

[7] Riduwan, Dasar-dasar statistika. Bandung: Alfabeta, 2010 